\title{
Outcontracting in Emergency Management: More Than a Business Conundrum
}

\author{
Yvonne Rademacher* \\ Disaster Research Center, University of Delaware, DE 19716, USA
}

\begin{abstract}
Outcontracting is a growing practice by governments as well as by nongovernmental organizations engaged in emergency management. Understanding the role of the private sector in providing equipment and services is critical in ensuring that emergency management is carried out as effectively and efficiently as possible in the best interest of the affected population. This inquiry looks at the types of services that the U.S. Federal Emergency Management Agency (FEMA) contracts out to both for-profit and not-for-profit organizations and examines the reviews that these services have received by government itself, interest groups, and disaster scientists. The article concludes with an overview of specific functional areas, where the services of either for-profits or not-for-profits are most appropriate in relation to their areas of expertise. The implication drawn from the analysis is that contractors' motivations and expertise need to be clearly understood when awarding government contracts in order to respond effectively to disaster needs and meet taxpayers' expectations.
\end{abstract}

Keywords emergency management, FEMA, for-profit contractor, government outcontracting, not-for-profit contractor, United States

\section{Introduction}

The trend of outcontracting has long been an established practice both in the private sector as well as in government. Over the past decade, outcontracting has progressively permeated virtually every function of emergency management. Not only government agencies but also increasingly not-forprofit organizations working in emergency and disaster management are making use of outside contractors for specific technical services and expertise in time-limited projects. The practice of outcontracting - traditionally already surrounded by controversy-has been accompanied by a particularly intense debate in the field of emergency management.

Employing services only when needed, better cost effectiveness, and limiting liability are some of the key arguments of supporters of contracting out services. Critics insist that this practice poses a threat to such fundamental pillars of

\footnotetext{
*E-mail: vonnie@udel.edu
}

emergency management as, for example, accountability and institutional memory. Are contractors indeed more cost-effective? Considering the range of technical expertise required for most projects, does it make sense to employ personnel full time when they may not be needed all year round? Beyond these financial and contractual issues, there is a more fundamental ideological question: is it ethical to profit from the misery of disaster-affected populations? Is it justifiable to make a profit when that money could make a substantial contribution to saving lives and a faster recovery? Is it fair that taxpayers' money or private donations in response to a disaster go into the profit pockets of a contractor? The very foundation of the concept of not-for-profit work in emergencies is challenged by the introduction of outcontracting - most controversially among not-for-profits now using for-profit contractors themselves.

This debate on the use of for-profit and not-for-profit contractors is not only an academic exercise. It poses a dilemma for emergency managers who are accountable to taxpayers and donors, and who, at the same time, see as their first priority serving those affected by disasters, which requires making the best possible management decisions, often under considerable funding constraints. In addition, organizational policies dictate the parameters for the use of contractors, thus adding another dimension to the discussion. Emergency managers have to carefully weigh the particulars of every situation - within the context of public opinion, organizational policies, administrative rules, and financial considerationsand determine whether the tasks at hand can be carried out by in-house staff, or whether it is more desirable to hire a contractor.

This study examines some key issues surrounding this debate with a particular focus on the use of for-profit and not-for-profit contractors in emergency management by the U.S. government. The first section looks at the advantages and disadvantages of using either for-profit or not-for-profit contractors. A discussion then follows that highlights where they diverge and what consequences this has for specific functional areas of emergency management that may be better served by one type of contractor over the other. Finally, this inquiry concludes with a look into the future and how the practice of outcontracting in emergency management is most likely to develop. 


\section{Government's Use of For-Profit Contractors}

Contractors are widely used by government. With an upsurge of private companies offering emergency related equipment and services, for-profit contractors have over this past decade also quickly permeated government entities with a mandate in emergency management, notably FEMA. With an inadequate number of core staff, according to the findings of the Department of Homeland Security's (DHS) Office of the Inspector General (DHS 2009), FEMA is only able to meet the demands of a disaster by augmenting its capacity virtually instantaneously through implementing and stand-by partners. A review of active contracts that FEMA currently administers reveals that the organization does not only issue contracts in times of disasters but also does so for routine tasks. This suggests that the agency's core staff is insufficient to manage even day-to-day tasks that fall within the organization's mandate. Of interest in the debate about the use of for-profit contractors are consequently the following questions: What are the main areas and situations where for-profit contractors are employed? What are the key arguments of proponents of for-profit contractors in emergency services? And why does the government choose for-profit over not-for-profit organizations in outcontracting?

As of April 7, 2011, FEMA advertised on its website that it administered a total of 490 active contracts (FEMA 2011a). Of these, 472 - or 96 percent - were with private for-profit contractors, while 12 were with academic institutions, 4 with other local government entities, and 2 with one nongovernmental organization (NGO) working not for profit, namely the American Red Cross (Table1).

The majority of the 96 percent of FEMA issued contracts that employ private for-profit contractors can be compartmentalized into two major categories: (1) support services, and (2) FEMA core functions. Under support services, the for-profit contractors mainly work in such areas as communications, project evaluations, records management, administrative clerical and contracts services, security support services, media advertising, business consulting, and report support services. Under what may be classified as FEMA core functions, these contractors carry out substantive emergency response tasks such as providing air and ground ambulances, setting up and maintaining mobile homes and mass shelters, providing electrical services for staging areas, removing snow, engaging in small infrastructure repair projects, and

Table 1. Overview of active FEMA contracts as of 7 April 2011

490 active FEMA contracts as of 7 April 2011

\begin{tabular}{cccc}
\hline $\begin{array}{c}\text { Private For-Profit } \\
\text { Contractors }\end{array}$ & Academia & $\begin{array}{c}\text { Local } \\
\text { Government }\end{array}$ & $\begin{array}{c}\text { Not-For-Profit } \\
\text { NGO }\end{array}$ \\
\hline $472(96.4 \%)$ & $12(2.4 \%)$ & $4(0.8 \%)$ & $2(0.4 \%)$ \\
\hline
\end{tabular}

Note: Data from FEMA 2011a. conducting exercises and training. FEMA also hires these contractors for jobs that would traditionally be handled by academia or research institutes. For example, FEMA has hired and continues to hire private firms to carry out emergency-related studies on climate issues, environmental and seismic activities, as well as analyses and reports on specific emergency management topics such as volunteer firefighters and the scientific mapping of emergency environments.

Moreover, despite FEMA's denial that it is hiring contractors for inherently governmental functions that should only be carried out by government personnel, the Office of the Inspector General of the Department of Homeland Security (DHS 2009, 17) has repeatedly found FEMA in violation:

Despite these requirements, contract staff are approving Staffing for Adequate Fire and Emergency Response grant payments without FEMA program personnel review and approval. Contract staff are also evaluating quarterly status reports submitted by Staffing for Adequate Fire and Emergency Response grant recipients. Our discussions with program and contractor personnel disclosed that Staffing for Adequate Fire and Emergency Response contractors have the authority to make decisions on payment requests and program status, which are prohibited activities according to OMB Circular No. A-76. As such, contractors are performing work that constitutes inherently governmental functions. FEMA has been using contract staff for these inherently governmental functions since 2006 due to lack of FEMA staff. The Staffing for Adequate Fire and Emergency Response program manager said that he does not have the time to "look over the shoulder" of the contract staff while they are reviewing quarterly reports and requests for funds.

This not only highlights the precarious human resources situation at FEMA, and demonstrates how consistently it relies on contractors to carry out its work, but also reveals how deeply contractors have penetrated the institutional structure and carry out core governmental functions with barely any oversight and accountability. While the discussion below looks further into some of these negative implications, the focus of this section remains on arguments about why it makes sense for FEMA to employ for-profit over not-forprofit contractors.

As Sylves $(2008,164)$ and others explain, outcontracting is popular with government because "contractors have more flexibility and freedom to complete work, and often at less cost, than government does." Disaster management is, in essence, largely "seasonal" project work. It is not economical for government to retain a large workforce in anticipation of a disaster and on permanent and costly employment contracts. It makes more economic sense to hire contractors when needed. In addition, as disaster management functions are becoming increasingly specialized and technical, it is sensible to hire contractors with specific skill sets when and where required. Some of these skills are indeed hazard-specific, such as the ongoing clean-up operation after hurricanes Katrina and Rita and the Deepwater Horizon oil spill in the 
Gulf. Sylves (2008) illustrates how large for-profit contractors such as Halliburton, Booz Allen Hamilton, Bechtel, and the Dewberry Company took over critical emergency response functions after Hurricane Katrina, particularly in terms of logistics, reconstruction, infrastructure repair, telecommunications, and environmental clean-up. In these instances, did the government have a real choice between hiring a for-profit or not-for-profit contractor?

Not-for-profit organizations generally work to provide essential social services to the general public or for a particular target group, such as the disabled, the elderly, or children. Well-known, national not-for-profit organizations engaged in emergency work are, for example, CARE, Save the Children, Habitat for Humanity, and the Red Cross. Their emergency services focus on providing emergency shelter, food, and clothing, to mention a few. Longer-term, not-for-profit organizations facilitate the community recovery and reconstruction process through the repair of minor community infrastructure, housing, and the restoration of livelihoods.

Returning to the list of functions for which FEMA currently employs contractors, only few fall into the expertise of not-for-profit organizations. Not-for-profits generally do not provide support services such as communications, project evaluations, records management, administrative clerical and contracts services, security support services, media advertising, business consulting, and report support services among other functions. Not even some of what we may classify as FEMA's core functions are activities that these organizations usually carry out, for example, snow removal or power grid and rail repair work, or even writing analytical and scientific reports and producing technical GIS products.

But not-for-profits have built expertise and a reputation in other areas where FEMA is continuously looking for partners. Setting-up and maintaining mass shelters, conducting exercises and training courses, and providing emergency medical services are some of those areas. Still, the data show that for-profits are hired for these traditional humanitarian activities. For instance, in order to speed up the response to Hurricane Katrina, FEMA entered into five contracts to address specifically the large-scale emergency housing needs (FEMA 2005). The five contractors included the Shaw Group, Fluor Corporation, Bechtel National Inc., CH2M Hill, and Dewberry Technologies. All of them are for-profit companies. The following questions then arise: Why does FEMA still prefer outcontracting to for-profits for these tasks? Can for-profits in fact mobilize resources faster and more efficiently than not-for-profits, even those with comparable expertise? Clearly, many not-for-profits do not have a local presence everywhere and also have to boost their own capacity in times of disaster. However, exactly this capability of being able to mobilize volunteers and community engagement virtually instantaneously has been one of their distinct advantages. The fact that many not-for-profits have started resorting to for-profit contractors themselves is a clear indication of the rapidly changing environment of emergency management in the United States and globally. A combination of a growing myriad of stakeholders, multilayered community, government and business interests, a private sector that offers increasingly competitive emergency services and equipment, as well as the complexities of technological advances pose challenges also to not-for-profits that extend beyond their capacities. For instance, the American Red Cross (ARC) explains in its 2010 Disaster Relief Program Review on the need to, at times, augment its own response capacity: "A disaster relief response requires a vast reserve of resources and volunteers. Managing these resources requires real estate, logistical support and vendor agreements that exceed local capabilities" (ARC 2011a, 12). In addition, the American Red Cross also issues calls for proposals for such services as feasibility studies (ARC 2011b). Although these examples are peripheral to the organization's core operation and selfimplementation, it is important for the government to understand what activities are subcontracted. Should not-for-profits now also start relying on for-profit vendors for some of their core activities - as is already the case in government and further discussed below with reference to the "hollow state"the government may as well work directly with those subcontractors instead.

The data on currently active contracts issued by FEMA hint that some work could have been carried out by a not-forprofit organization rather than the for-profit that eventually received the contract award. There may be a variety of reasons why a not-for-profit organization was not chosenincluding, possibly, that no not-for-profit applied for the contract, had sufficient organizational capacity to implement the contract, had a presence in a particular locale required for the contract, or that potential not-for-profits simply seized the moment of donor attention in times of disaster and appealed for direct funding instead of competing for a government contract. In these instances, FEMA would have had no choice but to employ a for-profit competitor. Available data do not provide conclusive insight into this decision-making process. Thus, these possible explanations require further study, which is beyond the scope of this article.

In summary, government now uses for-profit contractors in virtually every single functional area of emergency management. Flexibility and better cost-effectiveness seem to remain key arguments for their employment. In addition, the increasing need to meet specialized and time-limited demands in emergency services and the absence of sufficient human resources in government itself-as uncovered by the DHS Inspector General - facilitates a conducive environment for the privatization of the emergency management sector and the use of for-profit contractors specifically.

\section{Government's Use of Not-For-Profit Contractors}

As the data on FEMA-issued contracts shows, the government also hires not-for-profit contractors to support emergency management activities. Although contracts with not-for 
profits are proportionally virtually non-existent, FEMA appears to place an increasing emphasis on expanding its partnership base with the non-profit sector in ways other than by entering into contractual service agreements and in the spirit of the "Whole Community" approach. For instance, in 2010 FEMA signed a Memorandum of Understanding with national organization Voluntary Organizations Active in Disaster (VOAD) that is designed to improve communication and coordination. In the same year, FEMA enter into another agreement, this time with the Red Cross, that lays the foundation for shared responsibilities in mass care response during emergencies. Fusing the expertise of both organizations, the agreement "will combine the strength of FEMA as a federal agency and the decades of Red Cross experience in providing mass care to people in need" (ARC 2010). In order to complement the discussion above on for-profits, the following questions further explore the status of not-for-profits as potential contractors for the government: What are the key arguments of proponents of not-for-profit contractors in emergency services? What are the main situations and functional areas where not-for-profit contractors are employed? And why, if their expertise is so overtly recognized by government itself, are they not preferred government contractors?

In the United States, the legal status of non-profits is guided by tax laws under Section 501(c) (3) of the Internal Revenue Code, which stipulates that "The organization must not be organized or operated for the benefit of private interests, and no part of a section 501(c) (3) organization's net earnings may inure to the benefit of any private shareholder or individual." Sylves $(2008,158)$ further explains "By definition, a voluntary not-for-profit organization is one that provides service to a community free of charge or for the minimal cost that is required to defray the cost of the service(s) furnished. Financial support for voluntary agencies is generally through donations, contracts, and grants." FEMA (2011b) expands on this by clarifying that a non-governmental not-for-profit organization is:

An entity with an association that is based on interests of its members, individuals, or institutions. It is not created by a government, but it may work cooperatively with government. Such organizations serve a public purpose, not a private benefit. Examples of NGOs include faith-based charity organizations and the American Red Cross. NGOs, including voluntary and faith-based groups, provide relief services to sustain life, reduce physical and emotional distress, and promote the recovery of disaster victims. Often these groups provide specialized services that help individuals with disabilities. NGOs and voluntary organizations play a major role in assisting emergency managers before, during, and after an emergency.

Thus, these not-for-profit organizations can play three distinct roles vis-à-vis the government in times of emergencies and disasters: (1) they may be active on the ground through non-government funding and, at best, coordinate their efforts through stakeholder coordination mechanisms; (2) they may be active on the ground and participate in the operation with the assistance of FEMA grants; or (3) they may be active on the ground as a FEMA agent, employed by the government as a contractor. When hired for a contract, they have competed and have been selected for their expertise, track record, and capacity to manage the tasks at hand. In whichever of those three roles they participate in emergency-related activities, their organizational culture, human resources structure, and philanthropic objectives will not change, even when funding is now received through a government contract instead of through private donations. In fact, a non-profit often operates in the same emergency with different funding sources that may include a combination of governmental and nongovernmental financial support. Moreover, regardless of their funding source, non-profits remain accountable to their governing bodies - be it their membership or board - and the public they serve according to the organization's mission statement. The same holds true for for-profits, whose organizational structure and culture also does not change with the award of a government contract.

Consequently, the critical distinction between for-profit and not-for-profit contractors lies in their motivation and their corresponding work ethics. While not-for-profits work towards providing essential services for the "common good," the primary concern of a for-profit is the profit margin. One of the most employed FEMA contractors, the Shaw Group, emphasizes in its Executive Compensation and Governance Overview (The Shaw Group Inc. 2012, 4) that "Our number one goal is to create long-term value for our shareholders. Through our pay for performance program, we are striving to align the interests of our corporate management with the interests of our shareholders." Sylves $(2008,164)$ elaborates further that "government contractors, as profit-maximizing businesses, have an incentive to minimally meet the terms of the contract, nothing more. Some government contractors have been accused of being unresponsive to taxpayers or have been prosecuted for fraud and corruption." By contrast, a not-for-profit equivalent with comparable expertise in the housing sector is, for example, Habitat for Humanity. Its mission is guided by the objective of "seeking to eliminate poverty housing and homelessness from the world and making decent shelter a matter of conscience and action" (Habitat for Humanity 2012). Furthermore, with a future homeowner's own financial and manual labor contributions, "Habitat houses are sold to partner families at no profit and financed with affordable loans." These two examples highlight the fundamentally diverging perception of accountability and objectives of for-profits and not-for-profits, which are important to understand when entering into contractual agreements for emergency services.

By outsourcing, government inevitably loses some degree of oversight, accountability, and transparency. When dealing with assistance to disaster-affected populations, not only speed and volume of service delivery is crucial but also quality and "best fit." Consequently, beyond the specific provisions of the project contract, knowledge of the community and the degree of a vested interest in the longer-term building 
of community disaster resilience should also be a deciding factor for awarding contracts. This may help guard against an erosion of oversight and accountability resulting from outcontracting. Although not-for-profit organizations have not been immune from accusations of misuse of funds, the frequency and scale of contract fraud by for-profits have received particular attention. For instance, in the case of Hurricane Katrina, Trichur (2007, 231) - following the work of the government's Fraud Task Force - concludes that while investigations have focused on fraud by emergency assistance recipients, "instances of corporate contract and procurement fraud have been documented at fifty times that amount. The Shaw Group and other politically connected corporations like Halliburton and Bechtel seized lucrative deals for clean-up and reconstruction without competition or oversight, while regional companies in desperate need of help were cut off from the bidding process."

For not-for-profits, shared principles of sustainability apply. For instance, activities of the American Red Cross are guided by the principles of its charter, which specifically tasks the organization with devising and integrating sustainable programs spanning the mitigation, preparedness, and response phases of the disaster management cycle. Habitat for Humanity - as Steve Weir, Vice President of Global Program Development and Support explains-pursues sustainability as a holistic approach that incorporates "environmental sustainability, family and community sustainability, and financial sustainability" (Weir 2012). All not-for-profit organizations operate under shared humanitarian principles, which for example include the do-no-harm principle that stipulates that no organization engaged in humanitarian assistance should act in a way that may worsen the situation of those they have come to help. Not-for-profit organizations work closely with the community and are generally focused on the sustainability of their activities. This is also the reason why many remain in the community beyond the immediate response phase and attempt to ensure a steady transition from relief to recovery. Their community work usually continues beyond a government contract where continued funding can be secured through other sources.

By contrast, for-profit contractors have no interest in the community beyond their contractual work. Companies such as the Shaw Group, Fluor Corporation, Bechtel National Inc., $\mathrm{CH} 2 \mathrm{M}$ Hill, and Dewberry Technologies also have a corporate culture of engaging in charitable initiatives for the communities in which they work. However, the difference is that those community support initiatives are peripheral to their organization's core work. Thus, beyond time-limited contractual obligations, there are no comparable guiding principles for these for-profits intended to promote community sustainability and, more specifically where they implement a contract for emergency-related activities, the longer-term building of community disaster resilience. Consequently, the motivation - or lack thereof - to engage with the community and find "best-fit" solutions for recovery is distinctly different for not-for-profit and for-profit contractors. Government's use of not-for-profit contractors may constitute another strategy to ensure that emergency-related activities are firmly integrated into a more comprehensive and ongoing process of community sustainability and resilience.

Furthermore, a successful disaster response and recovery is inevitably dependent on the degree of community involvement. One of the approaches taken by not-for-profits during the initial response is to employ or otherwise engage the local community to the extent possible and then work towards the restoration of livelihoods long-term. Again, the principle of do-no-harm is applied, where non-profit organizations are committed inter alia to not distorting the local employment market and commodity prices by paying original local rates and working at local standards. For-profits do not adhere to these principles, employ and buy wherever "the price is right." This was experienced by local economies in Louisiana, Mississippi, Alabama, and Florida, which had already suffered enormously when a cheap workforce descended on their communities after Hurricane Katrina-leaving uncompetitive local workers who had just lost their livelihoods with few opportunities to find a new job. This situation was further exacerbated by President Bush lifting the Davis-Bacon Act that sets a minimum wage for workers on federal contracts. Thus, those contractors who worked on behalf of FEMA in response to Hurricane Katrina and Hurricane Rita were allowed by the Federal Government to employ workers at less than the 9 USD minimum wage in the region. President Bush justified his action by arguing that the wage rates imposed by the Act "increase the cost to the Federal Government of providing Federal assistance in these areas" and that the suspension "will result in greater assistance to these devastated communities and will permit the employment of thousands of additional individuals" (The White House 2005). American Federation of Labor and Congress of Industrial Organizations (AFL-CIO) President John J. Sweeney (AFLCIO 2005), on the other hand, was outraged and countered: "Employers are all too eager to exploit workers. This is no time to make that easier. What a double tragedy it would be to allow the destruction of Hurricane Katrina to depress living standards even further." Democratic Representative George Miller of California went further by accusing the Administration of exploiting this national tragedy by "awarding billiondollar no-bid contracts to cronies like Halliburton, but think that local workers in the Gulf struggling to get back on their feet after Katrina are being overpaid" (U.S. House of Representatives 2005). A week later in a letter of 13 September 2005, Miller and fellow members of Congress petitioned the Comptroller General on their concerns of government outcontracting in emergencies, which in their view benefited a few private companies through, among others, no-bid contracts and on a cost-plus basis. They urged the Government Accountability Office to put into place more rigorous oversight measures in order to better protect the interests of beneficiaries and taxpayers. This example shows how powerful business interests in U.S. emergency management are and 
how far they extend into the workings of government entities. Moreover, it is an example of the divergent ideological views that exist on the use of "profit" during humanitarian emergencies.

Looking at the current practice of contract awards, U.S. emergency management provides a conducive environment for for-profit contractors. Arguments for the use of not-forprofits include greater accountability to the affected population as well as more appropriate services that incorporate longer-term strategies. Areas in which not-for-profits continue to remain successful are emergency relief services, including shelter, food, clothing, emergency medical aid, and psycho-social support, as well as longer-term community rebuilding and livelihood restoration.

\section{Suggested Functional Areas for Government Contractors}

The discussion above has highlighted where non-profit and for-profit contractors currently work, what key issues have provoked controversy over their engagement in emergency management, as well as what their respective strengths are. Although there are ideological and ethical arguments that a "for-profit" approach has no place in emergency management and that a "profit" should not be made on the misery of disaster-affected populations, the reality is that a disaster by definition overwhelms existing capacity, which is currently addressed by the U.S. government through the hiring of a range of contractors, mainly for-profits.

The following table (Table 2) provides a suggestion as to which specific areas the two types of contractors-taking their respective expertise into consideration - may be best suited. These functional areas are examples from the list of currently issued FEMA contracts matched with the areas of expertise, as discussed above, by both for- and not-for-profits. The table does not constitute a complete list of all possible activities that may require the hiring of a contractor in case of a disaster. Also, as the Office of the Inspector General

Table 2. Overview of suggested functional areas for government contractors

\begin{tabular}{lll}
\hline & Short-Term & Long-Term \\
\hline For-Profit & Disaster Area & FEMA Internal \\
& - communications & - media, advertising \\
& - security support services & - training and exercises \\
& - air and ground ambulances & - smalli nfrastructure \\
Not-For- & - utility services & repair \\
Profit & - small infrastructure repair & - IT support \\
& - emergency shelter & Disaster Area \\
& - clothing & - longer-termc ommunity \\
& - emergency medical aid & - housing \\
& - psycho-social support & \\
\hline
\end{tabular}

commented (DHS 2009), there are certain functions that should not only remain under the control of government but should also be carried out by government personnel themselves, primarily to guard against a conflict of interest but also to maintain appropriate oversight and accountability. For this reason, contractors should not be given responsibility for certain tasks, which would include, for instance, records management as well as administrative clerical and contract services.

\section{The Future of Outcontracting in U.S. Disaster Management}

As long as there is consensus that emergency management is a "shared national responsibility" (Roberts 2010, 43), which government is tasked to coordinate and guide, appropriate resources have to be available to meet this responsibility. In light of tighter government budgets in the foreseeable future, an increase in government personnel cannot be expected. Therefore, in addition to expanding stakeholder networks and non-governmental resources, entities such as FEMA will undoubtedly have to continue to rely on contractors to carry out core functions and boost capacity in times of national disasters.

Roberts and others argue that this trend of outsourcing leaves a "hollow state" and, paradoxically, actually increases the need for government: "FEMA, like other agencies, contributes to the "hollow state" by locating much of its capacity outside government, as when it enters into contracts with private firms to provide public services. These firms create a state within the state, a network of firms whose employees are not subject to government regulations but who perform functions once carried out by federal employees ... Privatization actually increases the need for government coordination (though not direct control) over the growing network of organizations responsible for emergency management" (Roberts 2010, 59). It remains to be seen to what extent the "hollow state" is acceptable to the American public and the American taxpayer.

Kirschenbaum (2004) and Handmer (2000) contend that the trend of outsourcing and privatizing has already created a private emergency management sector that has shifted the perception of "national responsibility" towards one of individual choices. They believe that taking a business approach focused on demand and supply sets a process in motion that will more and more start focusing on actual individual needs and, thus, eventually serve disaster-affected communities better. The U.S. government practice of outsourcing has increased competition and led to a proliferation of private companies engaged in emergency equipment, technologies, and services. The effect has been a steady increase in the private sector taking over core governmental functions but also, at the same time, providing emergency services to individuals and businesses directly. 
Kirschenbaum (2004) carried out a study in Israel on consumer demand for emergency supplies and services, which were also provided by the government for free. In his investigation of the potential of privatizing the emergency management sector related to all phases of the disaster management cycle, Kirschenbaum (2004) concluded that the privatization of public sector disaster services was sensible as consumers regardless of their economic standing were prepared to pay for emergency equipment and services even if those were provided gratis by the government. The reasons for this appeared to range from more options in terms of selecting their preferred equipment or services to a perceived better quality.

Kirschenbaum's study pertains to emergency management in a distinct security environment in Israel. Therefore, its findings are not easily transferable to other countries. But as privatization of emergency management is well underway also in the U.S., a similar study of American consumers would be helpful in gaining an insight into what types of equipment and services they would be willing to pay for themselves. This would provide an opportunity for government to recalibrate its organizational framework of disaster management, refocus its resources, and provide only those services that individuals are not able to provide for themselves.

Moreover, as the complexity and economic losses of disasters increase (UN 2011) and government resources with which to respond to the growing challenges become scarcer-thus, ultimately, placing a greater burden on individuals and local disaster management institutions - taxpayers are also likely to raise more questions about whether the profit approach to emergency management is indeed appropriate and effective. Ultimately, the issuing of contracts to both for-profits and not-for-profits will largely depend on what the government is able to afford and where its priorities lie.

\section{Conclusion}

The U.S. Government is currently dependent on both for-profit and not-for-profit contractors in carrying out its responsibilities in emergency management. Both types of contractors have limitations in terms of their areas of expertise. Therefore, government has to choose carefully when and where to employ either. The argument of more efficiency and better cost-effectiveness by for-profit contractors requires further research. Whether or not a for-profit disaster management approach is acceptable from an ideological perspective is a matter of national consensus. The current prevailing ideology in the U.S. is in support of an expanding for-profit business model. In order to safeguard against conflicts of interest and ensure the most appropriate and sustainable assistance to disaster-affected communities, government needs to be vigilant in entering into contracts that adequately meet taxpayers' expectations and longer-term community needs.

\section{References}

AFL-CIO (American Federation of Labor and Congress of Industrial Organizations). 2005. AFL-CIO President John J. Sweeney Statement on Executive Order Waiving Davis Bacon on Federally Funded Hurricane Reconstruction. Press Release, 8 September 2005. http://www. aflcio.org/mediacenter/prsptm/pr09082005.cfm.

ARC (American Red Cross). 2010. Red Cross to Share Mass Care Responsibility for U.S. Emergencies. News Release, 22 October 2010. http://www.redcross.org.

_. 2011a. Delivering Relief, Inspiring Hope - 2010 Disaster Relief Program Review. http:/www.redcross.org/www-files/Documents/ pdf/domestic\%20programs/DisasterReliefProgramReview.pdf.

- 2011b. Request for Proposal. Feasibility Study on Multi-Purpose Community Disaster Centers in Haiti 2011. 16 March 2011. http:// www.europeanevaluation.org/images/file/Jobs/2011-05-12_ARC RFP-Feasibility_study_on_Community_DM_centers-Haiti.pdf.

DHS (Department of Homeland Security). Office of the Inspector General. 2009. Improvement Needed in Federal Emergency Management Agency Monitoring of Grantees. OIG-09-38. Washington, DC: Office of Inspector General, Department of Homeland Security.

FEMA (Federal Emergency Management Agency). 2005. FEMA Contracts to Provide Housing Relief for Displaced Hurricane Victims. Press Release Number HQ-05-228, 8 September 2005. http://www. fema.gov/news/newsrelease.fema?id=18708.

. 2011a. Active Contracts as of April 7, 2011. http://www.fema.gov/ pdf/business/activecontracts.pdf.

- 2011b. Glossary. http://www.fema.gov/oer/reference/glossary. shtm.

Habitat for Humanity. 2012. Fact Sheet. http://www.habitat.org/how/ factsheet.aspx.

Handmer, J. 2000. Are Emergency Services Becoming Private? The Australian Journal of Emergency Management 15 (3): 42-45.

Kirschenbaum, A. 2004. Chaos Organization and Disaster Management. Public Administration and Public Policy. No. 105. New York: CRC Press.

Roberts, P. S. 2010. Private Choices, Public Harms: The Evolution of National Disaster Organizations in the United States. In Disaster and the Politics of Intervention, edited by A. Lakoff, 41-69. New York: Columbia University Press.

The Shaw Group Inc. 2012. Executive Compensation and Governance Overview. http://www.shawgrp.com.

Sylves, R. T. 2008. Disaster Policy and Politics: Emergency Management and Homeland Security. Washington, DC: CQ Press.

Trichur, G. K. 2007. Spectacular Privatizations - Perceptions and Lessons from Privatization of Warfare and the Privatization of Disaster. In Racing the Storm - Racial Implications and Lessons Learned from Hurricane Katrina, edited by H. Potter, 225-46. Lanham, MD: Lexington Books.

UN (United Nations). 2011. Global Assessment Report on Disaster Risk Reduction. Geneva, Switzerland: United Nations International Strategy for Disaster Reduction.

U.S. House of Representatives. Committee on Education and the Workforce. 2005. Representative Miller to Force House to Vote on President's Gulf Coast Wage Cut. Press Release, 20 October 2005. http://www.house.gov/apps/list/press/edlabor_dem/rel102005.html.

Weir, S. 2012. Sustainability: A Holistic Approach. The Forum. Habitat for Humanity. http://www.habitat.org/theforum/english/sustain/ holistic_approach.aspx.

The White House. Office of the Press Secretary. 2005. Proclamation by the President: To Suspend Subchapter IV of Chapter 31 of Title 40, United States Code, within a Limited Geographic Area in Response to the National Emergency Caused by Hurricane Katrina. Press release, 8 September 2005. http://georgewbush-whitehouse.archives. gov/news/releases/2005/09/20050908-5.html.

Open Access This article is distributed under the terms of the Creative Commons Attribution License which permits any use, distribution, and reproduction in any medium, provided the original author(s) and source are credited. 